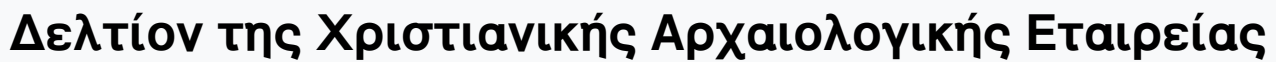

Tó 17 (1994)

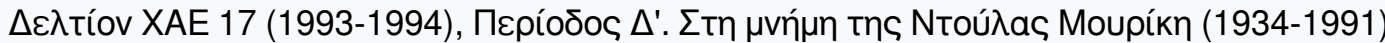

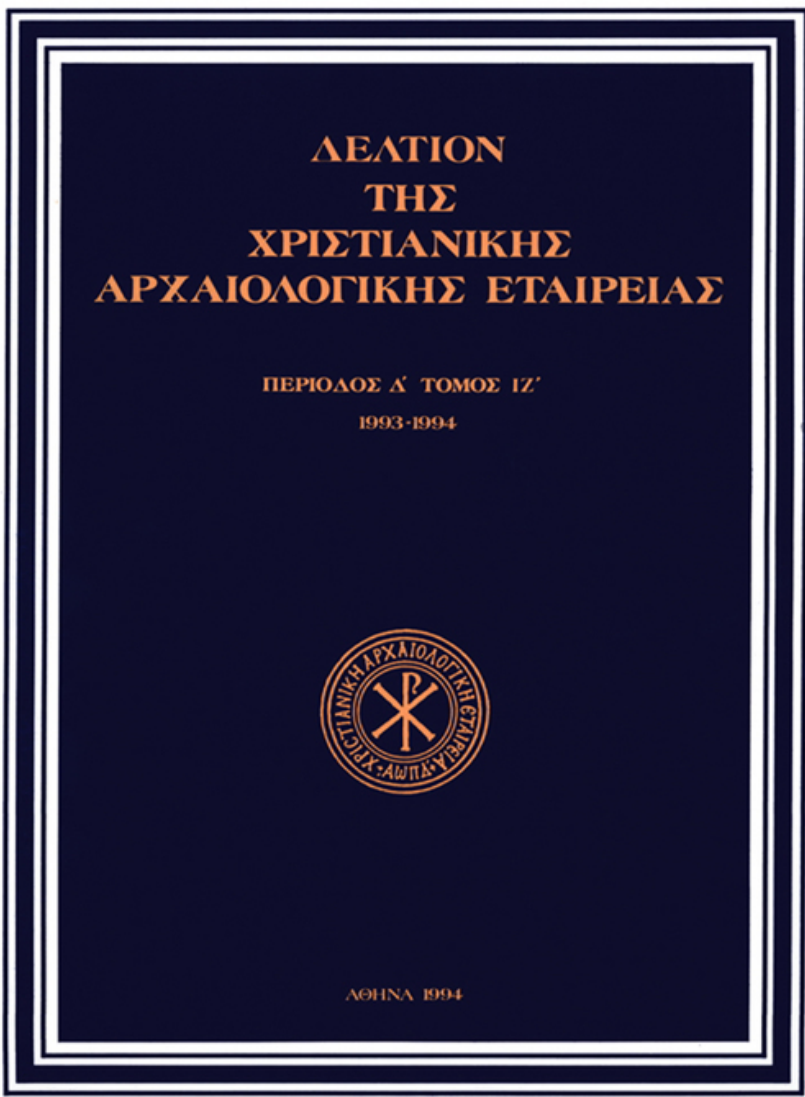

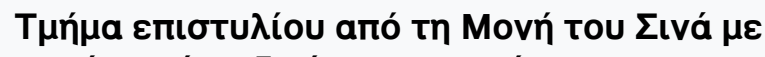

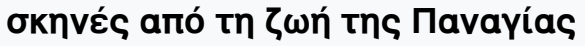

Mary ASPRA-VARDAVAKIS

doi: $\underline{10.12681 / \text { dchae. } 1113}$

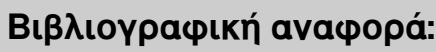

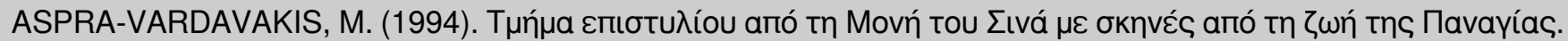

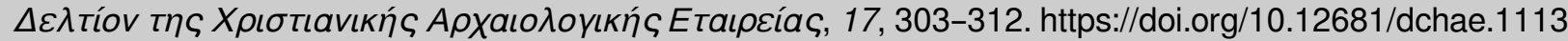




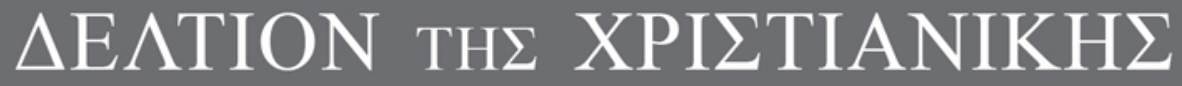 APXAIO $\Lambda$ OГIKH $\Sigma$ ETAIPEIA $\Sigma$}

Section of an Iconostasis Beam from the Monastery of Mount Sinai with Scenes from the Life of the Virgin

Mary ASPRA-VARDAVAKIS

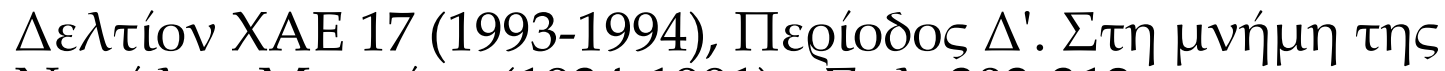

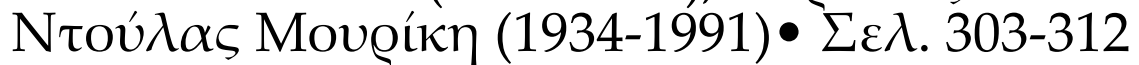

A@HNA 1994 


\section{SECTION OF AN ICONOSTASIS BEAM FROM THE MONASTERY OF MOUNT SINAI WITH SCENES FROM THE LIFE OF THE VIRGIN*}

$I_{t}$ is common knowledge that the Collection of the Monastery of St. Catherine on Mt. Sinai includes an exceptionally large number of icons from the 6th to the 18 th century. The icon under study here, is one of those post-Byzantine icons which can be dated by stylistic criteria to the 15 th century, and constitutes part of an iconostasis beam.

The standard repertoire reserved for these beams from the 12th century onwards includes the Twelve Feasts of the Orthodox Church (the so-called Dodecaorton) which are presented below painted or relief arches. Depending on the beam's size, the repertoire could be enriched with other scenes from the Life of Christ or the Virgin, while the centre is taken up by a Deesis. Of the iconostasis beams preserved in the Sinai Monastery, some are complete, while only sections of others have survived. They date from the 12 th to the 15 th century. The iconostasis beam that concerns us here, is unpublished. It is the only one which includes scenes from the Life of the Virgin ${ }^{1}$, but unfortunately it is not complete. The only extant section measures $73 \mathrm{~cm}$ long, and 34.2 $\mathrm{cm}$ in height. The width of the border is $3.5 \mathrm{~cm}$ and the thickness of the board $2.7 \mathrm{~cm}$. The epistyle is divided by a relief colonnade ${ }^{2}$, into three compartments taken up by four scenes from the Life of the Virgin (Fig. 1). Jointly depicted in the compartment to the left are the Annunciation of the birth of the Virgin to Anne and the Annunciation to Joachim. The Birth of the Virgin takes up the middle compartment and the scene to the right is that of the Seven First Steps of the Virgin. The condition in which the iconostasis beam has been preserved is very good, except for a sinuous crack running through its centre lengthwise, whose sides are held together at the back by a piece of hessian soaked in glue. Minor interventions in black paint can be seen here and there, especially in the hair of St. Joachim, of the shepherd, of the Virgin Mary, on the headdress and the shoes of St. Anne in the scenes of the Birth of the Virgin and of the Seven First Steps respectively.

\section{The Annunciation to St. Anne and to St. Joachim}

The protagonists of the two episodes are depicted standing in a rocky setting, surrounded by trees in bloom ${ }^{3}$. On the left, St. Anne stands in prayer, accepting the message of the flying angel. She wears a cypress-green chiton and a red maphorion. The angel, who is depicted up to the thighs, wears a blue-green chiton, a crimson himation, and the outside surface of his wings are painted black, while the inside is red. The outline of the haloes is engraved; on St. Anne's somewhat clumsy attempt has been made to draw a second outline. The inscription reads: AANA I POCEYXOENH (sic) (Fig. 1). From an iconographical point of view, the Annunciation to St. Anne fails to comply with tradition ${ }^{4}$. The main elements of the scene, namely Anne's house, the garden with the spring, the trees and the birds, have been replaced here by a rocky landscape essentially associated with St. Joachim's stay on the mountain, in the narration of the Pseudo-Matthew (III.1), since the Protevangelium refers to Joachim setting up his tent in the desert (I.4).

St. Anne is also depicted against the background of a rocky landscape in the corresponding scene on the right panel of a triptych in the Monastery of Mount Sinai of the Hodegetria Aristerokratousa, which portrays scenes

\footnotetext{
* I wish to extend my thanks to His Beatitude the Archbishop Damianos and the members of the Holy Synaxis of the Monastery of St. Catherine for giving me the permission to publish the icons and for the photographic material.

1. Another beam is that of St. Eustathios, where indeed, no scenes from the Dodecaorton appear. G. and M. Sotiriou, Eiksóves $\tau \tilde{\eta} \varsigma$

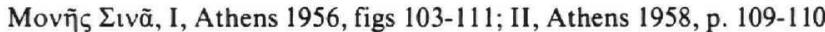
(hereafter: Icons). See also D. Mouriki, Icons from the 12 th to the 15th Century, Sinai. Treasures of the Monastery, Ekdotike Athenon, Athens 1990, fig. 20 (in colour).

2. This has been done in low relief. The iconostasis beams from the Monastery of Mount Sinai we have been familiar with up to date have painted arches, while those from the Athos monasteries are in relief. See, Sotiriou, Icons, II, p. 377, n. 1; M. Chatzidakis, Eikóve $\zeta$ émı 3. The depiction of the two episodes in one representation is often found in monumental painting from the end of the 13th century and

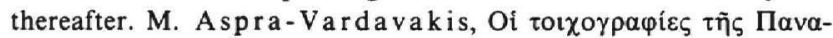

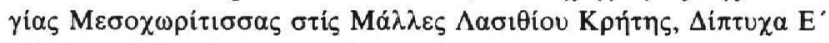
(1991), p. 215, where examples can be seen.

4. See J. Lafontaine-Dosogne, Iconographie de l'enfance de la Vierge dans l'empire byzantin et en Occident, I, Bruxelles 1964, p. 68ff.
} 


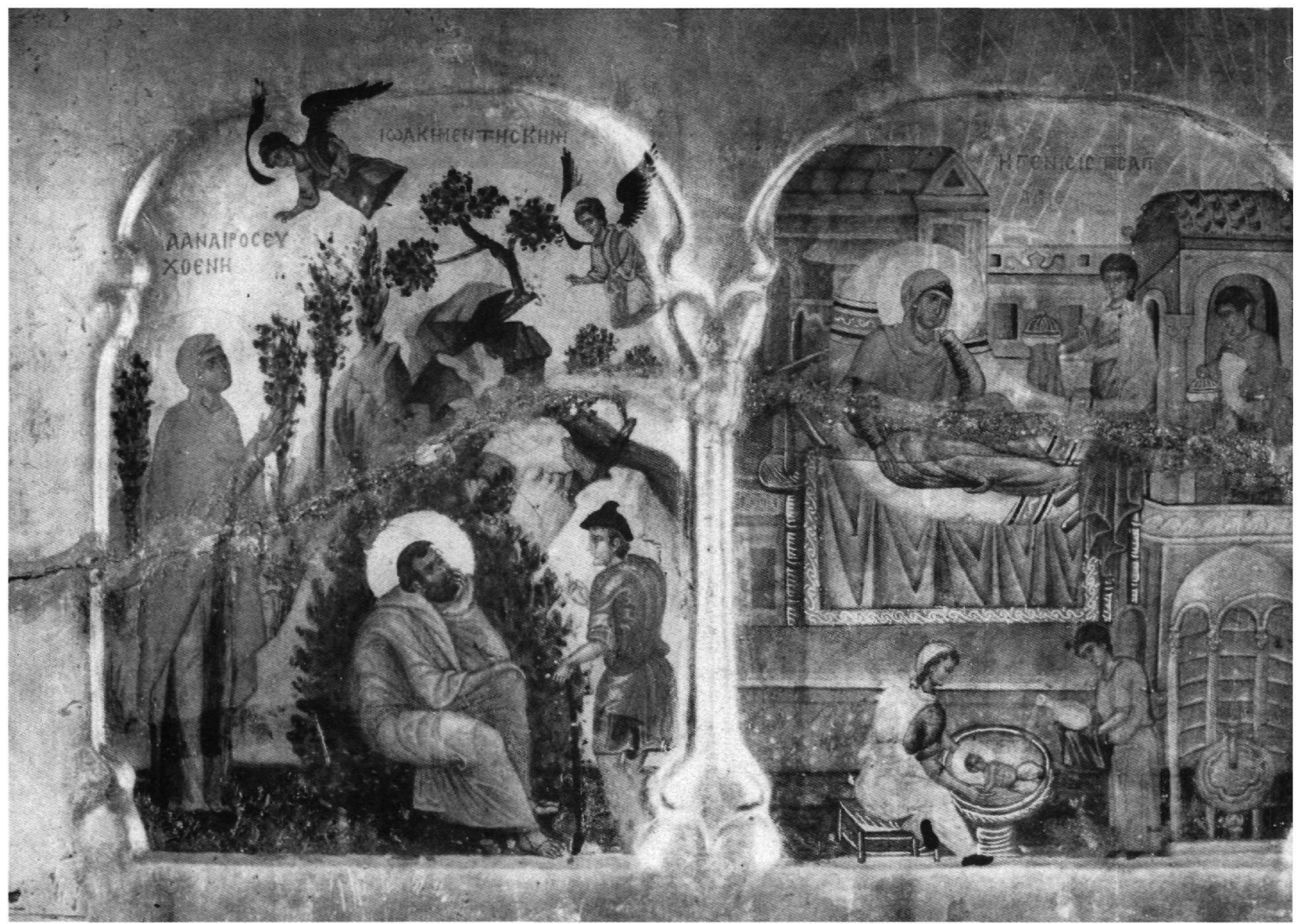

Fig. 1. Sinai. Monastery of St. Catherine. Fragment of an iconostasis beam with scenes from the Life of the Virgin.

from the Virgin's life and has been dated to the early 13 th century ${ }^{5}$ (Fig. 2). The icon is known in the Monastery as the "Bematarissa", due to its position on the bema of the katholikon, behind the Holy Altar ${ }^{6}$. In the same painting can be seen the representational prototype of St. Anne, as is shown by the typological similarity of her face and the arrangement of her maphorion, which reveals a large portion of her headdress.

Next to St. Anne, and inside a hut made of the branches of a bush in bloom, St. Joachim is seated, and the inscription reads: ISAKHM EN TH CKHNH (Joachim in the tent). He is dressed in a rose-coloured himation with golden yellow ochre highlights and is encircled by a golden halo. He is resting his head on his left hand and seems to be listening intently to the words of the youthful figure portrayed opposite him in a dancing position - he is standing on tiptoe. The young man is wearing a short crimson chiton, red stockings, a hat and is carry- ing a black staff. He has the appearance of a shepherd, but his right hand is lifted in blessing (Fig. 1). This detail indicates that he is most probably meant to be the angel who, in accordance with the narration of the PseudoMatthew (III.1-2), appeared to Joachim in the form of a young man, asking him why he did not return to his wife. After Joachim tried to offer excuses, he revealed himself as the angel of God and announced that Anne had conceived a child?

A second flying angel is portrayed above right. His chiton is blue-green, his himation rose-coloured and his wings are black and grey on the inside. His figure, however, does not seem to be linked to that of St. Joachim, but to that of St. Anne, judging by his gaze which is directed towards her. Here, besides the Annunciation to St. Anne and to St. Joachim, we probably have the announcement of the return of St. Joachim to St. Anne, always according to the Pseudo-Matthew (III). 


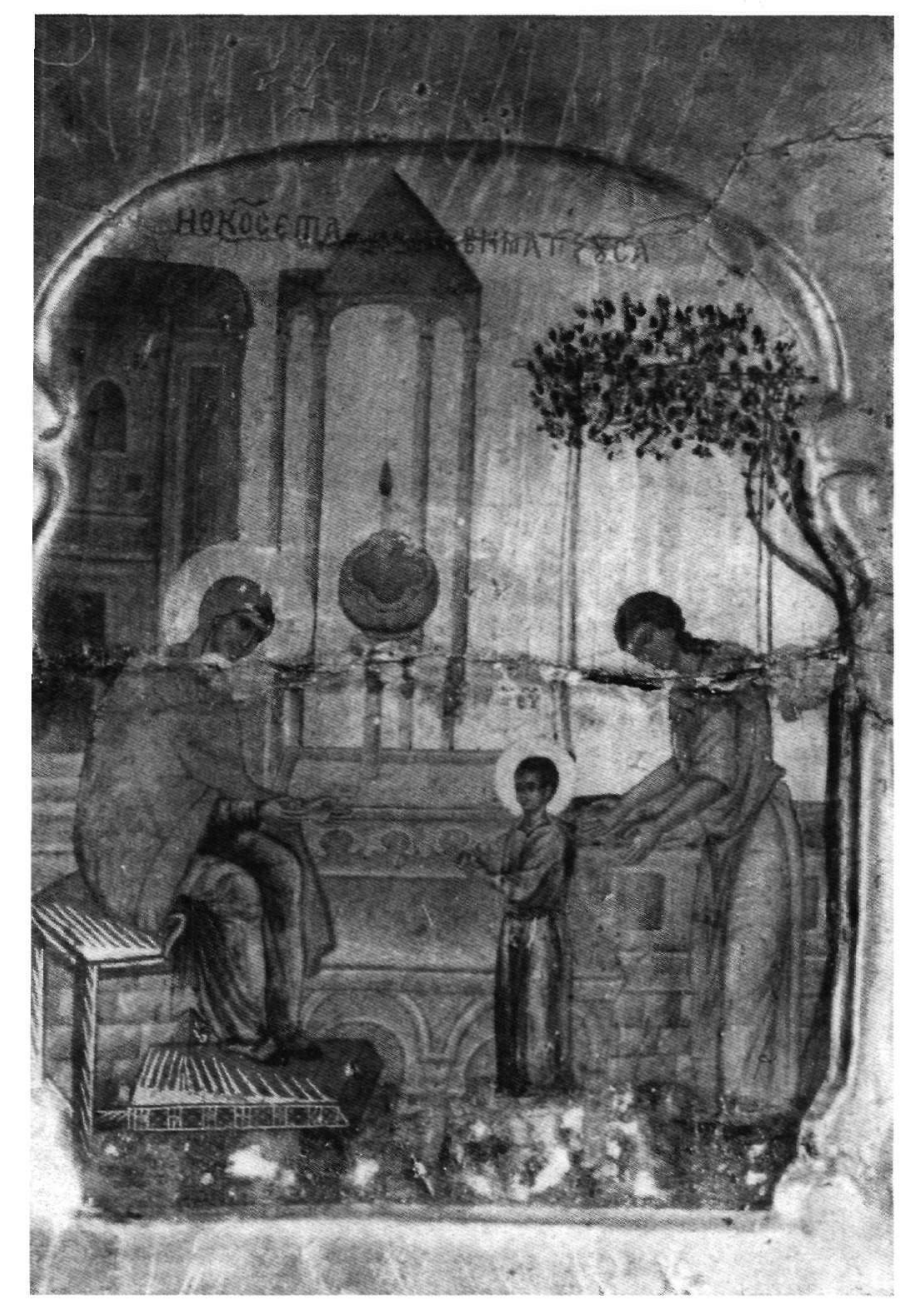

\section{The Birth of the Virgin}

On the left, in a cypress-green chiton and a red maphorion, St. Anne is portrayed sitting up in a particularly wide bed covered with an embroidered bedspread. The bed dominates the elevated area of her luxurious home. She seems lost in thought, indifferent to the presence of the two young women offering gifts. The first woman, dressed in a deep crimson chiton and an ivory-coloured mantle, is offering a precious pyxis as a gift to the woman in childbed. The second woman, holding the same kind of gift in her hands, appears on the balcony of the building on the right, behind the dividing wall. She is wearing an ivory-coloured chiton and a red mantle. Lower down, on the first level of the scene, is depicted the baby's bath. Further to the right, a fountain with a water-spout embellishes the complex architectural decoration of the representation. The inscription reads: $\mathrm{H}$ ГENHCIC THC AГIANAC (sic) (Fig. 1).
The scene is in accordance with the iconographical tradition ${ }^{8}$ of the 11 th and 12 th centuries, while the painter seems to have combined elements from various older icons in the Monastery. Anne's pose and the morphology and fittings of the bed ${ }^{9}$ find an echo in two unpublished Sinai icons which, on stylistic grounds, can be dated to the second half of the 13 th century ${ }^{10}$ (Figs 3, 4, 5 , and 6). The same may be said of the servant-girl, pouring water from a pitcher into the basin for the Virgin's bath, and to the midwife whose garment and headdress have been differentiated. The young woman offering Anne gifts in a metal vase, and the pronounced architectural background, resemble a similar depiction on the well-known iconostasis beam with two scenes from the Life of the Virgin together with the Dodecaorton, installed in the last quarter of the 12th century (Fig. 7). Similarities can also be observed between the two scenes with respect to the organization of space despite the morphological differences in the buildings. We

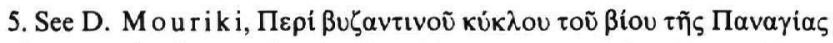

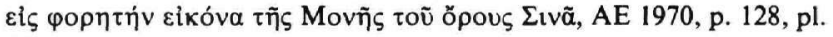
$45(\delta)$.

6. Ead., Icons from the 12 th to the 15 th Century (s. note 1), p. 112 , figs 54-55 (in colour). However, the fountain and perhaps also the house of St. Anne are not absent, as is evidenced by a part of the building in the far left of the scene, behind the rocks. It is quite possible that the marked presence of trees in bloom in the scene on the iconostasis beam suggests the "paradise" of her house.

7. Eodem tempore apparuit quidam juvenis in montibus Ioachim... dixitque ad eum. Quare non reverteris ad uxorem tuam?... Ego sum angelus dei, qui apparui hodie uxori tuae...

8. See Lafontaine-Dosogne, Iconographie, p. 91ff.; ead., The Life of the Virgin, in: P. Underwood (ed.), Studies in the Art of the Kariye Djami, 4, New York 1966, p. 174ff.

9. Of similar conception is the bed of St. Anne in the mosaic on the same subject at Daphni. The representation of the icon from Mount Sinai also has other common iconographical elements with Daphni mosaic, such as the attitude of St. Anne, which is rendered with greater elegance, the draping of her maphorion which allows part of her headdress to show, and the depiction of the bath of the Virgin only, and not that of her cradle. G. Mille t, Le monastère de Daphni, Paris 1899, pl. XVIII.

10. Certain elements of their ornamentation, such as the painted pearls on the haloes of the figures, the series of gilded lozenges on a black and red background, or of pearls combined at intervals with precious stones on their frames, classifies them at what are known as "Crusader" icons. See K. W eit z m a n n, Thirteenth Century Crusader Icons on Mount Sinai, ArtB XIV (1963), p. 182, 183, figs 3, 4, 5, 18, 3; id., Icon Painting in the Crusader Kingdom, DOP 20 (1966), p. 66, figs $14,22,23,24$, etc. The gilded lozenges bear a golden ornamentation in relief which has been considered as originating in Cyprus and having been brought back to the West by the Crusaders. See M. Frinta, Relief Decoration in Gilded Pastiglia on the Cypriot Icons

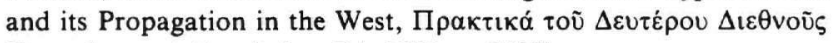

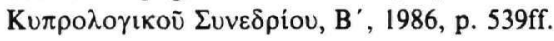


should note the dividing wall with the cornice, behind which the young women appear, the wall in the background between the two buildings, as well as the important role in linking the whole arrangement played by St. Anne's lavishly decorated bed.

The Virgin at her bath, wearing undergarments only round the waist, constitutes a hapax ${ }^{11}$ while the fountain with the cone-like water-spout, together with the absence of a baldachin, is found in the corresponding scene on both Crusader icons (Figs 4,6). The presence of a fountain, inside a house, should not be seen as mirroring aristocratic living conditions in the East, but as being of symbolic significance. In the East, the pinecone, since very ancient times, was considered a fertility symbol, especially in the cults of Mithras and Attis, and this symbolism seems to have been retained in the Christian period ${ }^{12}$. Consequently, the presence of the covered fountain with the cone-like water-spout serves to stress the fertility of the aged Anne. A spring with a similar water-spout is often included in the Annunciation to Anne, as in Daphni ${ }^{13}$, for example, while worth noting also is the cone-shaped ornamentation on the bedspread of the Holy Virgin in the scene of the Birth of the Virgin in the same church ${ }^{14}$.

\section{The Seven First Steps of the Virgin}

On the first level of the scene and in the centre, the young Virgin advances, arms outstreched, towards her mother, who, seated on a gold-inlaid stool on the left, is ready to catch her up. The Virgin is dressed in a cypressgreen robe with golden-yellow ochre highlights and a red maphorion. On the right, a young maiden follows the Virgin's steps, her arms outstreched protectively. She is wearing a rose-coloured robe with golden-yellow ochre glints.

On the second level of the composition, to the left, rises a tall and narrow building. There is a fountain in the centre, with a water-spout, a cistern and, linked to it, a stone-table supported by low arches. To the right is a climbing vine, while a wall built in opus isodomum limits the space (Fig. 1). Some of these elements, i.e. the house, the fountain in conjunction with the water cistern, trees instead of the climbing vine, are known to us from the scene of the Annunciation to St. Anne and are associated with the "paradise" of her house (Protev. II. 4).

The scene, follows tradition in terms of the number of figures, but the environment in which these figures are moving is unusual in its iconography. Of course, the high social standing of the Virgin's parents justifies the luxurious house with its pleasant surroundings, but noteworthy here, is the emphasis in the depiction of all
Fig. 2. Sinai. Monastery of St. Catherine. The triptych of the Hodegetria Aristerokratousa and scenes from her Life.

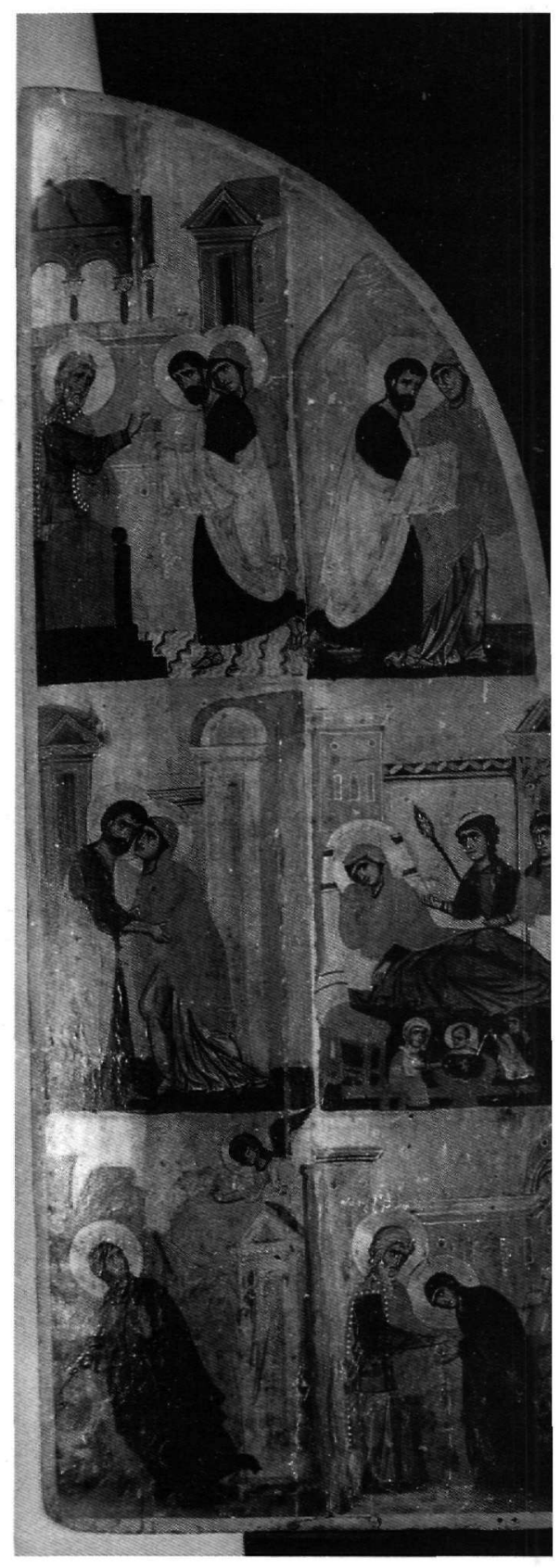

these architectural elements and that of the grape-vine. It is a fact that one cannot rule out the existence of hidden symbolisms. These elements clearly indicate that, other things aside, a mystical relationship between the two main protagonists in the scene, is concealed, to which a clearer explanation can be found in poetic texts related to the Virgin; or, they may reflect the ifluence of other literary sources, such as the "ekphrasis". Thus, the impressive fountain with the cistern, from which no 
tury) on the "paradise" of Saint Anne using a painting for a model, much emphasis is also placed on the element of the fountain, which stands in the centre of the garden, as well as on its elaborate ornamentation, while the colour of the precious materials of its various component parts is also mentioned: green for the basin, blue for the water-spout and crimson for its cone. There is also a garden and a multitude of trees, among which there are also vineyards. Statues, artificial birds and others, chirruping and singing, as well as rare flowers, complement the scene of this marvellous "paradise" 16 . In the scene of the iconostasis beam which we are examining, the fountain which dominates the centre of the composition is also green, while the water-cistern is crimson - we must note the decoration on its lip - as is the stone-table supported on arches, with its elaborate relief decoration, and the garden wall with the square niches in its upper part.

The iconographic model for the seated figure of Anne is

Figs 3-4. Sinai. Monastery of St. Catherine. Icon. The Birth and the Presentation of the Virgin to the Temple.

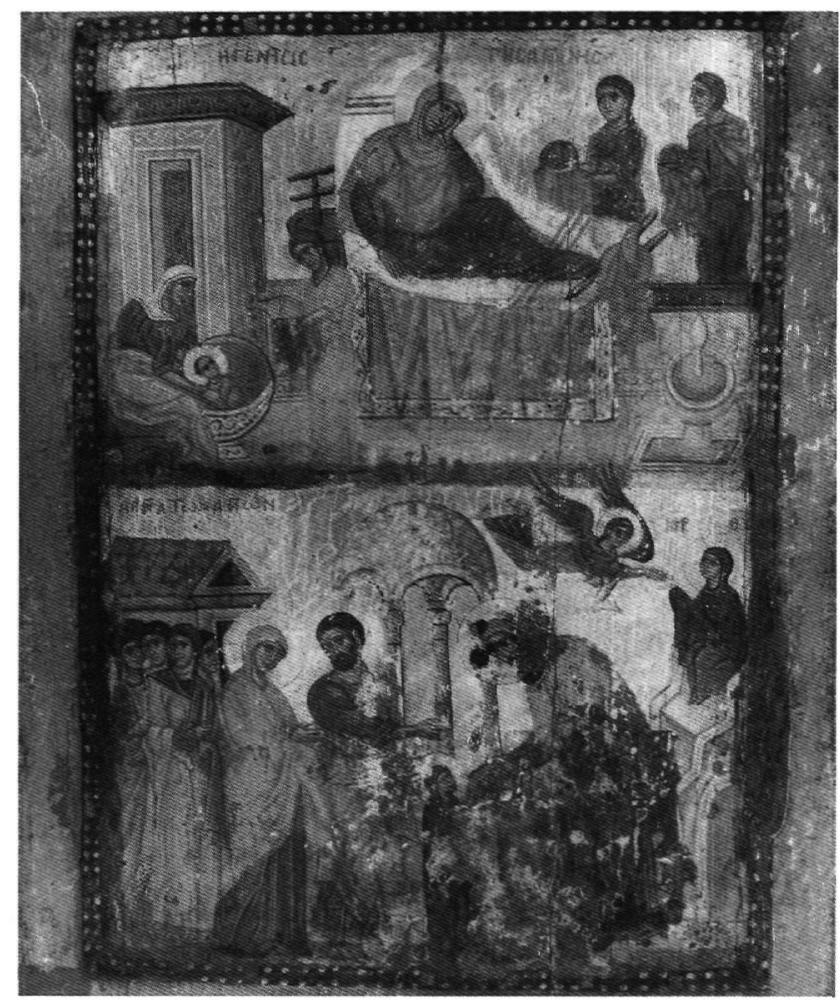




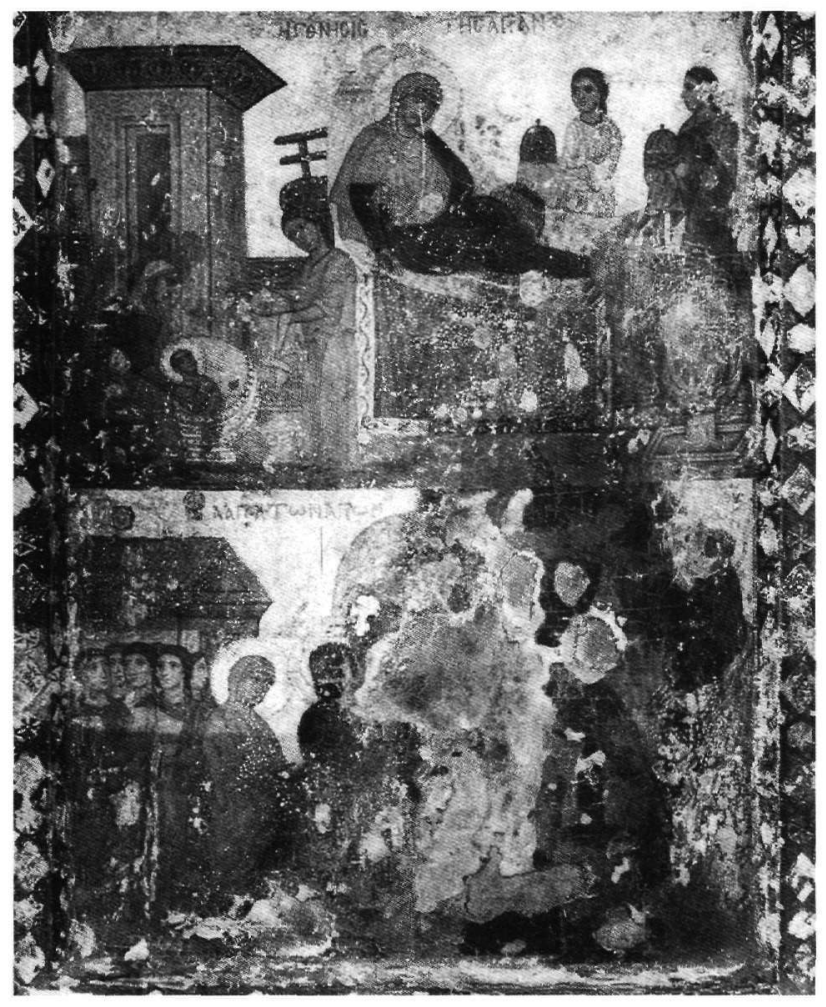

drawn from the scene of the Caresses of the Virgin, on the right panel of the triptych of the Hodegetria and the scenes of her Life (Fig. 2), while the model for the servant-girl tending the Virgin could be a figure similar to that of Salome from the Nativity in the above-mentioned iconostasis beam with the two-scenes from the Life of the Virgin together with the Dodecaorton (Fig. $8)$. The small figure of the Virgin with her very short

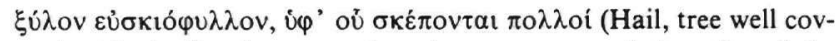
ered with shading leaves, under whom many are sheltered) and the

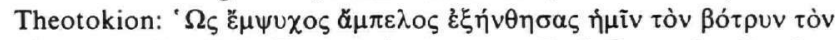
$\pi \varepsilon ́ \pi \varepsilon ı \rho v^{\prime . . . ~ S e e ~ C . ~ A . ~ T r y ~ p a ~ n ~ i s, ~ F o u r t e e n ~ E a r l y ~ B y z a n t i n e ~ C a n t i c a, ~}$

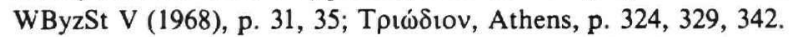

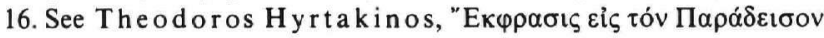

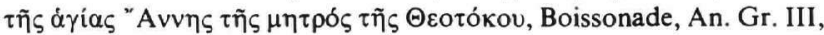
59-70. H. Hunger, Die hochsprachliche profane Literatur der

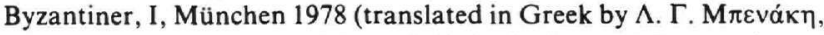

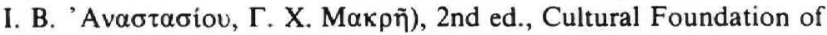
the National Bank of Greece, Athens 1991, p. 280.

Figs 5-6. Sinai. Monastery of St. Catherine. Icon. The Birth and the Presentation of the Virgin to the Temple.

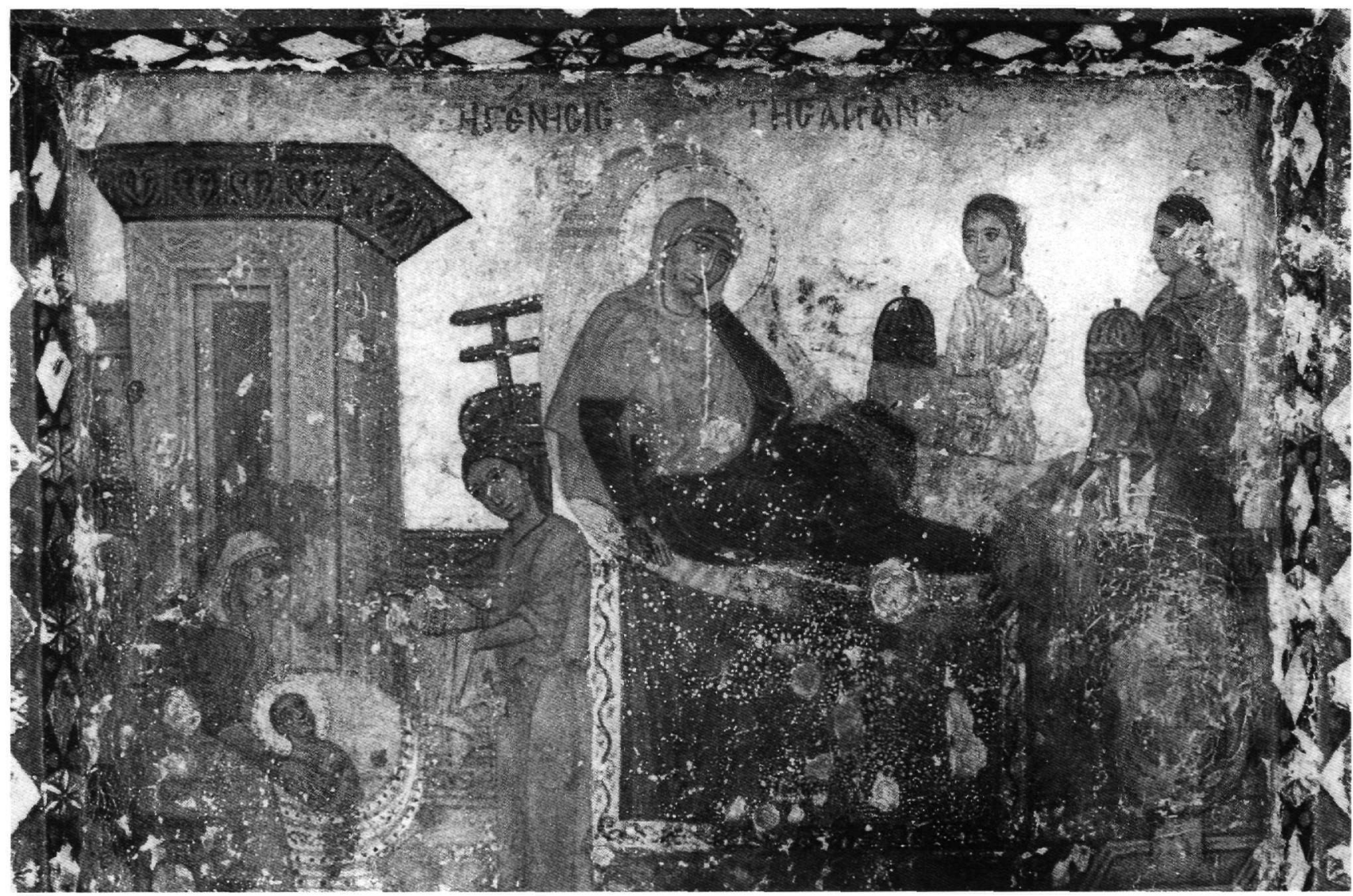


hair and without the traditional maphorion constitutes an innovation ${ }^{17}$. There is a considerable likeness here with her figure in the mosaic of the Presentation of the Virgin to the Temple, in Daphni. Although the Virgin wears a maphorion, this does not hide the tender, childish face framed by the short hair ${ }^{18}$.

The painting was executed on canvas. The luxurious impression evoked by the work can be attributed to the excellent quality of the gold ground, to the wood sculpture and to the manner in which the chrysography rechnique has been employed (for example, in the furniture, the fittings of Anne's bed, the vases with the offerings of the young women, and the basin with the Virgin's bath), as well as to the handling of the colours. The figures are tall and elegant, with small heads, closer to the classical conception of bodily proportion and reproduction of drapery. The figures also bear an organic relationship to the space in which they move. These elements place the work in general lines within the framework of a rather Pseudo-Palaeologan art. Moreover the rendering of the facial types - the fleshiness of the face in conjunction with the small eyes, the long nose and small mouth and their realistic character, conform to a date around the second half of the 15 th century.

The brief iconographic analysis above, highlights to a great extent, the influence which other icons in the monastery exerted on the painter of the iconostasis beam. This fact may help determine a possible provenance for our icon, namely within the Monastery of Sinai itself. Despite the fact, that we know of the existence of a local workshop in the second half of the 15th century ${ }^{19}$, extant evidence is insufficient, to allow us to arrive at more specific conclusions on the work of interest to us here. On the other hand, examination of the technique used on the iconostasis beam may provide us with some useful information.

The chromatic tones used for the flesh are a warm ochre with red, used to mould inner surfaces and olive shades are restricted for the extremities of the face. White highlights are diffused, rendering a great sense of plasticity. The free brushstrokes create quite a painterly result without any linear emphasis being given to the contours. The hair is modulated with brushstrokes in dark and light brown. Generally speaking, the execution is fine, only very slightly calligraphic, and the figures have a warm and most intimate expression. This rechnique is the same as that encountered in the wall-paintings of the small chapel in the north wall of the monastery which, by virtue of their small size, were executed with the finesse and care characteristic of portable works ${ }^{20}$. Another similarity is that between the rendering of the somewhat flaccid hands, the expressionless calm, due to

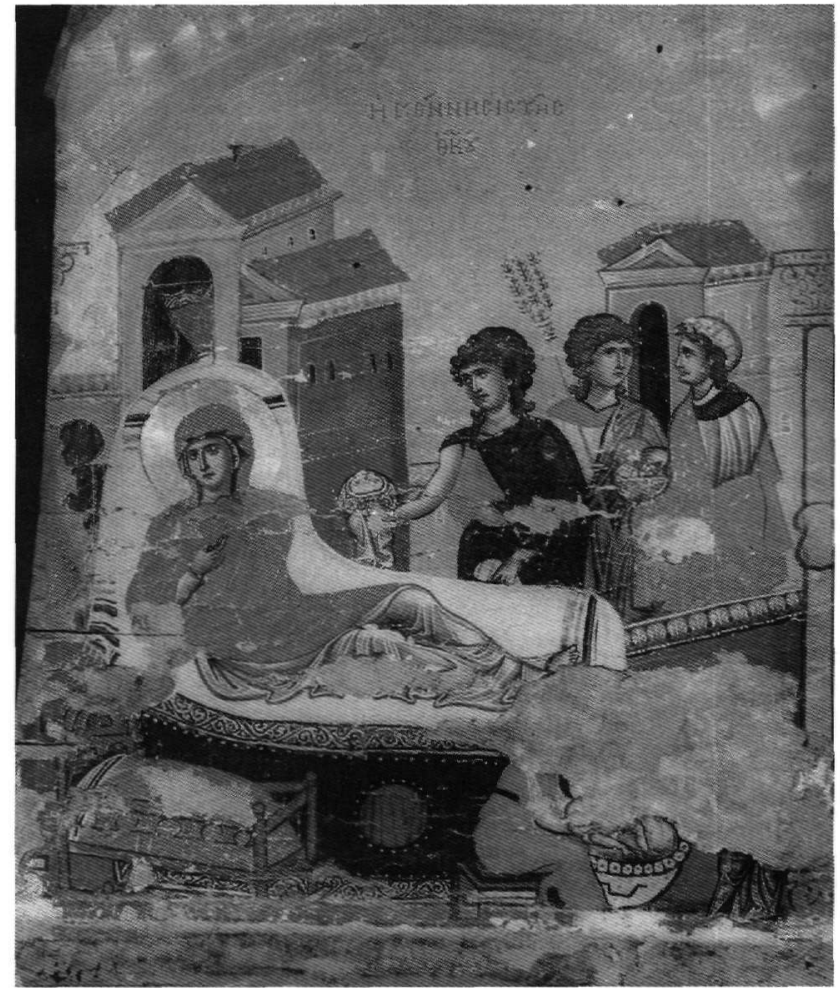

Fig. 7. Sinai. Monastery of St. Catherine. Epistyle with Dodecaorton and two scenes from the Life of the Virgin. Detail.

the soft and tranquil moulding of the features and perhaps the limpness of the drapery. On the other hand, there is a difference in the physiognomical types.

Comparison of these figures with their iconographical prototypes highlights common points of reference in the shape of the face, the poses and gestures, the details of dress, and in many cases in the fidelity of the colours ${ }^{21}$. St. Anne, for instance, in the scene of the Annunciation on the iconostasis beam, compared to her figure in the corresponding scene of the triptych with the Virgin Hodegetria, though differing in analogies, retains the same broad, angular face supported by a slender neck, the same expression and character, the summary rendering of the drapery, the ornamental function of the lights in the chiton, as well as the quality of the colours (Fig. 2). Similar remarks could be made regarding her representation in the scenes of the Nativity and the Seven First Steps of the iconostasis beam, and in those of the Nativity and the Caresses of the Virgin in the Crusader icons and the triptych, correspondingly (Figs 4, 6, and 2). Also instructive are the comparisons between the young woman bringing an offering to the woman in childbed, in the scene of the Birth of the Virgin, and that of the 
young woman in the analogous representation of the iconostasis beam, from the end of the 12th century (Fig. 7) as well as between the servant-girl following the steps of the Virgin in the scene of the Seven First Steps and of Salome in the earlier iconostasis beam (Fig. 8). In both these cases, despite certain differences, the painter has retained the studied pose, the aristocratic appearance and the refinement of the character of the figures, determinative elements of their capital city prototype. The drapery is rendered in deep tones of the base colour and tones of warm and light ochre, used to highlight protrusions. As regards the use of light, the painter is at every stage influenced by his model, but his results are often quite different from the original as is evident from, for example, a comparison between the scenes of Anne in the First Steps of the Virgin on the beam, and the Caresses of the Virgin, on the triptych panel, in the scenes of her Annunciation, on both works, or in the Birth of the Virgin on the beam and in the two Crusader icons. The light in the figures of the epistyle has an organic function in that it highlights the form of the body covered by clothing, as in the figures of Joachim in the first panel (Fig. 1) and of Anne and the servant-girl in the third, a trend which is reminiscent of older works from the 11th and 12th centuries. By this technique, clothes adhere softly to the body, as though they were "wet", following the figure's movement and enhancing its plasticity. The chromatic scale is not rich, but its tones are luminous. We must note the artist's care in alternating colours, particularly red and green for the clothing and the architectural elements, and gold for the background.

The three compositions present a special interest as regards their structure. The main theme is emphasized by its positioning in the first level, as well as through the scale of the figures, while no emphasis is placed on the central axis. Extreme care has been taken to achieve a detailed rendering of an almost naturalistic landscape in the scene of the Annunciation to Anne and Joachim (Fig. 1 ), which conveys springtime atmosphere with the blossoming trees and branches of Joachim's hut.

The rocks function as fragmented blocks, piled together to frame the shape of the leafy hut in front of them; what contributes to their realistic appearance is the fact that their granite surfaces catch different intensities of light depending on the time of the day. The impression of relief is achieved by the marked contrasts in light and shade and by the projection of their lighter sides in front of the shadowy surfaces of the rocks further back. This sensitivity in the rendering of landscape is known to us from works of the metropolitan art of the 14th and 15th centuries, such as, for example, that of the Monastery of the Hora in Constantinople (Kariye Djami) and of the Pantanassa at Mystras ${ }^{22}$. However, the shading and the soft line give the icon a more painterly style and echo techniques which pertain to western works of art.

The aspiration to achieve complexity, which is particularly obvious in the scene of the Birth of the Virgin, is diminished in importance by the organization of the form and the architectural elements in the upper and lower part of the composition in alignment. Thus, the central axis is dispensed with, and three verticals are

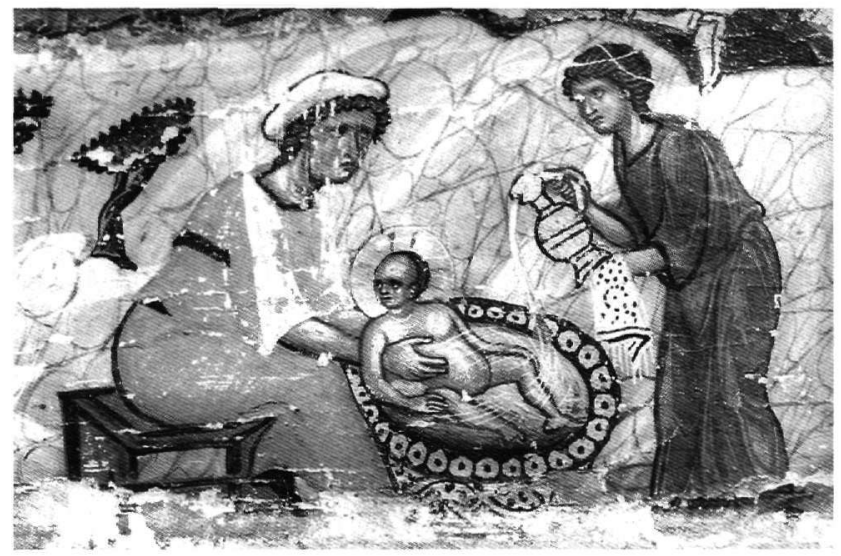

Fig. 8. Epistyle with Dodecaorton and two scenes from the Life of the Virgin. Detail.

17. Lafontaine-Dosogne, The Life of the Virgin, op.cit. (note 8), p. $122 \mathrm{ff}$.

18. Millet, Daphni, pl. XIX.2. Compare also the figure of the young Jacob in the cod. Vat. gr. 1162, f. 137v with which the Virgin has similarities in pose, dress and scale, C. St ornajolo, Miniature delle Omilie di Giacomo Monaco (cod. Vatic. gr. 1162) e dell'evangeliario greco urbinate (cod. Vatic. urbin. gr. 2), Roma 1910, fig. 60.

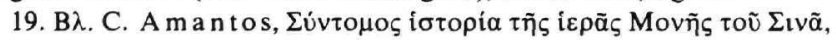

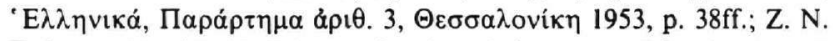

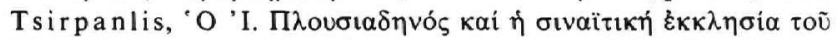

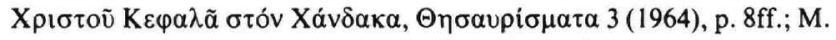

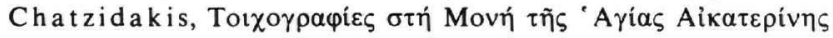

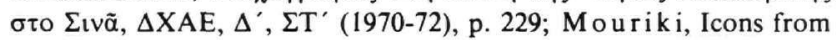
the 12 th to the 15 th Century (s. note 1), p. 123.

20. Chatzidakis, op.cit., p. 223, pls 77-80. A. Paliouras, Wall Paintings, Sinai. The Treasures of the Monastery. Ekdotike Athenon, Athens 1990, figs 24, 25 (in colour).

21. The colours, which are complex, characterize other icons of the Monastery as well, bearing a clear Sinaitic stamp, such as that of the Great Deesis and the various orders of saints which have been dated to the 15 th century. See Mouriki, Icons from the 12 th to the 15 th Century (s. note I), fig. 76, p. 125.

22. P. Underwood, (ed.), The Kariye Djami, 2, New York 1966, pl. 111. M. Chatzidakis, Mystras, Ekdotike Athenon, Athens 1985, figs 64, 66. D. Mouriki, The Wall Paintings of the Pantanassa at Mistra: Models of the Painter's Workshop in the Fifteenth Century, The Twilight of Byzantium, Princeton 1991, pls 10, 16. 
created through the figures of St. Anne's bed and of Salome, roughly in the centre, and that of the porch and the fountain, to the right. The dark purple colour on almost all the surfaces of the interior of St. Anne's house, that is on the raised platform on which her bed stands, on the surface of the wall behind the fountain, the porch and the wall between the buildings, combined with the golden background, lends a particular weight and solemnity to the scene. Did the artist perhaps wish to present the Virgin as "born to the purple"? An initial attempt at perspective, in the arrangement of the buildings and the furniture, as well as the impression of a specific source of light coming from the right, as we gather from the lighting of the apertures, are clear evidence of an endeavour to emphasize the third dimension.

There are, however, also cases where the artist appears not to understand the principles of the conventional perspective, if we go by the rendering of the fountain complex in the scene of the Virgin's Seven Steps. It is clear that there is no organic link between its elements, since the fountain and the water-cistern are in fact outside the baldachin which supposedly should cover them ${ }^{23}$ (Fig. 1). As a result of the clumsiness in the drawing of the stone-table, the row of the arches which support it projects into the first level of the composition, its lines becoming enmeshed with those of the figures. Here, neither, is there the device of the central axis, which would have brought into prominence the most important figure of the scene. The illusion of depth is created by the slant given to the building in the background, to the stool and to the figure of the seated St. Anne on the left, of the servant-girl on the right, as well as by the difference in height of the architectural elements in the centre of the scene - stone-table, watercistern, fountain. The artist attempted to correct the anomaly created by St. Anne's foot-rest, which is relatively large and rendered frontally by adding considerable comb-shaped chrysography on the one side; the same does also for St. Anne's stool. The grape-vine, on the other hand, is a realistic element which gives life to the composition, converting it into a scene from everyday life.

The painter's pronounced eclecticism together with the limited number of works, that have till now been attributed to the Sinaitic workshop, make us hesitate in attributing this particular iconostasis beam to it. Doubts also exist as to the national origins of the painter. Some of the iconographic details based on the text of PseudoMatthew, the misspellings and especially the strange syllabication of the inscriptions give rise to questions. We can with some certainty affirm, however, that the beam was painted at Sinai in the second half of the 15 th century, probably by an itinerant painter, and that it was meant for one of the chapels dedicated to the Virgin.

23. See also the fountain in the scene of the Virgin's Birth (Fig. 4). 